\title{
Joan of Arc's relics exposed as forgery
}

\section{PARIS}

The relics of St Joan of Arc are not the remains of the fifteenth-century French heroine after all, according to European experts who have analysed the sacred scraps. Instead, they say the relics are a forgery, made from the remains of an Egyptian mummy.

Joan was burned at the stake in 1431 in Rouen, Normandy. The relics were discovered in 1867 in a jar in the attic of a Paris pharmacy, with the inscription "Remains found under the stake of Joan of Arc, virgin of Orleans". They were recognized by the Church, and are now housed in a museum in Chinon that belongs to the Archdiocese of Tours.

Philippe Charlier, a forensic scientist at Raymond Poincaré Hospital in Garches, near Paris, obtained permission to study the relics from the French church last year. He says he was "astonished" by the results. "I'd never have thought that it could be from a mummy."

Charlier and his colleagues didn't have much to work with: the relics comprise a charredlooking human rib, chunks of what seem to be carbonized wood, a 15-centimetre fragment of linen and a cat femur - consistent with the medieval practice of throwing black cats onto the pyre of supposed witches.

\section{Sniff tests}

The researchers used a battery of techniques to investigate the remains, including mass, infrared and atomic-emission spectrometry, electron microscopy, pollen analysis and, unusually, the help of the leading 'noses' of the perfume industry: Sylvaine Delacourte from Guerlain, and Jean-Michel Duriez from Jean Patou.

Odour analysis is a new technique for palaeopathology, but Charlier says that he hit on the idea after being struck by the variety of odours of other historical corpses. Delacourte and Duriez sniffed the relics and nine other samples of bone and hair from Charlier's lab without being told what the samples were. They were also not allowed to confer. Both smelled hints of 'burnt plaster' and 'vanilla' in the samples from the relics.

The plaster smell was consistent with the fact that Joan of Arc was burnt on a plaster stake, not a wooden one, to make the whole macabre spectacle last longer. But vanilla is inconsistent with cremation. "Vanillin is produced during decomposition of a body," says Charlier. "You would find it in a mummy, but not in someone who was burnt."

Other, more conventional, evidence point-

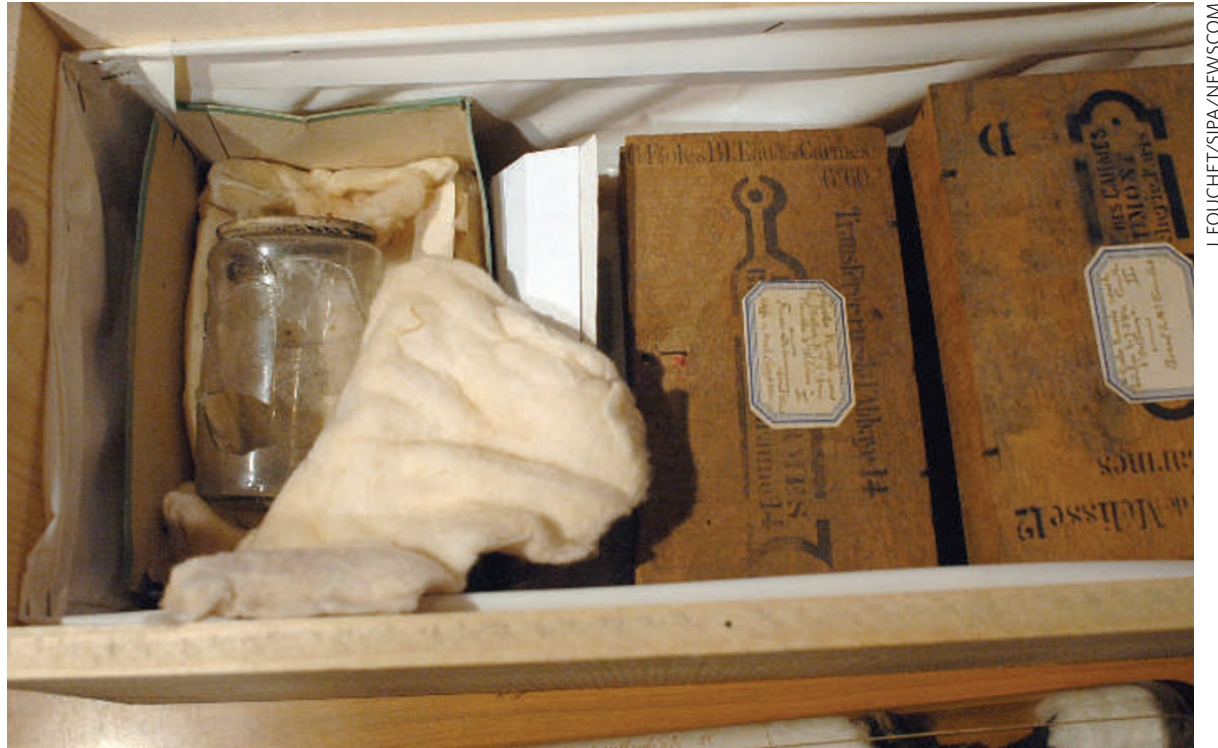

A vanilla smell of the alleged remains from Joan of Arc suggested natural decomposition, not burning.

ing to a mummy origin quickly accumulated. Microscopic and chemical analysis of the black crust on the rib and on the cat femur showed that they were not in fact burnt, but were impregnated with a vegetal and mineral matrix, with no trace of muscle, skin, fat or hair. "I see burnt remains all the time in my job," says Charlier. "It was obviously not burnt tissue."

The black material was, however, consistent with an embalming mix of wood resins, bitumen and chemicals such as malachite. It was also consistent with gypsum, which gives the mix its plaster smell. The linen cloth had a coating characteristic of mummy wrappings. And large amounts of pine pollen were present. Pine trees did not grow in Normandy at the time that Joan of Arc was killed, but pine resin was used widely in Egypt during embalming.

wo other lines of evidence seem to clinch the mummy origin. Carbon-14 analysis dated the remains to between the third and sixth centuries BC. And the spectrometry profiles of the rib, femur and black chunks matched those from Egyptian mummies from the period, and not those of burnt bones.

Charlier points out that mummies were used in Europe during the Middle Ages in pharmaceutical remedies. The 1867 discovery date also fits the period when Joan of Arc, who had been forgotten for centuries, was rediscovered by historians and created as a national myth. Someone might have forged the relics at this time in an attempt to reinforce her importance.

"It is a fascinating project," says Anastasia Tsaliki, a palaeopathologist at the University of Durham, UK. Palaeopathology is a small but emerging field that attempts to use forensic science to inform history, traditionally a social science. "Philippe's work goes a step further by showing how forensic methods can be combined with tools used in archaeometry, archaeobotany and osteology," says Tsaliki.

\section{Fire-proof organs}

Part of the legend of Joan of Arc springs from the observation, documented in historical records, that some of her organs resisted the fire. Hundreds of pages of surviving manuscripts describe in vivid detail how she was burnt three times over to try to ensure that nothing but ash remained, and so prevent her remains being worshipped. The observation of remaining organs was interpreted as a miracle.

But science has another explanation. "In fact, it is very difficult to totally cremate a body; organs such as the heart and intestines, which have a high water content, are very resistant to fire," says Charlier. "We see it all the time in forensics."

Debunking the relics of Joan of Arc will be less controversial than doing the same for the Shroud of Turin, but is still likely to generate large public interest, especially in France. The Church is ready to accept the results, according to Charlier.

Declan Butler 